\title{
THE ANALYSIS OF ABNORMAL RETURNS AND TRADING VOLUME ACTIVITY BEFORE AND AFTER SIMULTANEOUS GENERAL ELECTION IN THE YEAR 2019 (STUDY OF STOCKS THAT ARE INCLUDED IN THE JAKARTAISLAMIC INDEX)
}

\author{
Niki Aulia Dewi \\ auliadewi.alan@gmail.com \\ Jurusan Akuntansi Fakultas Ekonomi dan Bisnis Universitas Mataram \\ Lukman Effendy \\ lukman.effendy@unram.ac.id \\ Jurusan Akuntansi Fakultas Ekonomi dan Bisnis Universitas Mataram \\ Indria Puspitasari Lenap \\ indrialenap@unram.ac.id \\ Jurusan Akuntansi Fakultas Ekonomi dan Bisnis Universitas Mataram
}

\begin{abstract}
Political events are one of the factors that influence a country's economic conditions. The capital market as an economic instrument cannot be separated from various environmental influences, both economic and non economic environment. The aim of the research is to find out the difference of abnormal return and trading volume activity between 10 days before and 10 days after Simultaneous General Election 2019 on the stocks included in the Jakarta Islamic Index. The sampling method in this study was conducted using saturated samples of 30 companies. Statistical analysis method used is Paired Sample T-Test and Wilcoxon Signed Ranks Test. The result ofstatistical test shows that variabel abnormal return and trading volume activity produce the conclution that there is no difference in abnormal return and trading volume activity between 10 days before and 10 days after Simultaneous General Election 2019 on the stocks included in the Jakarta Islamic Index. The implications of this study for issuers do not need to worry about Simultaneous General Election information because the event does not significantly influence on abnormal return and trading volume activity.
\end{abstract}

Keyword : Simultaneous General Election, abnormal return, trading volume activity

\section{PENDAHULUAN}

Peristiwa politik menarik yang terjadi di tahun 2019 ini adalah pemilihan umum tanggal 17 April 2019. Tahun ini pertama kalinya Pemilihan Umum (Pemilu) dilaksanakan secara serentak, menggabungkan pemilihan anggota Legislatif dan juga pemilihan Presiden dan Wakil Presiden. Pemilu serentak dilaksanakan berdasarkan hasil keputusan Mahkamah Konstitusi (MK) yang mengabulkan gugatan Akademisi Effendi Ghazali bersama Koalisi Masyarakat untuk Pemilu Serentak terhadap UU Nomor 42/2008 tentang Pilpres. Dikutip dari theindonesianinstitute.com, alasan mereka sederhana, penyelenggaraan pemilu serentak lebih efisien baik dari segi waktu maupun biaya.

Bursa Efek Indonesia (BEI) menyebut situasi politik tanah air pasca pemilihan umum menimbulkan kekhawatiran di pasar modal, dikutip dari cnnindonesia.com, hal ini menjadi salah satu pemicu laju Indeks Harga Saham Gabungan (IHSG) merosot. Dalam sepekan, dari tanggal 10 hingga $17 \mathrm{Mei}$, data BEI mencatat IHSG turun sebesar 6,16 persen ke level 5.826,87 dari 6.209,12. Sejalan dengan itu, RTI Infokom menyebut investor asing mencatatkan beli bersih (net sell) sebesar Rp3,16 triliun dalam sepekan.

Beberapa peneliti telah melakukan penelitian yang berkaitan dengan pengaruh 
peristiwa politik terhadap pasar modal antara lain Lehkonen \& Heimonen (2015) menemukan bukti bahwa risiko demokrasi dan politik memang berdampak pada pengembalian pasar saham dan hubungan antara risiko demokrasi dan politik bersifat parabola yaitu, ada tingkat ambang demokrasi setelah itu risiko politik mulai menurun. Sedangkan Goodell \& Vähämaa (2013) menemukan bahwa hubungan antara volatilitas dan probabilitas pemilihan presiden adalah positif. Temuan ini menunjukkan bahwa proses pemilihan presiden menimbulkan kecemasan pasar ketika investor membentuk dan merevisi harapan mereka mengenai kebijakan ekonomi makro di masa depan.

Penelitian Pamungkas et al. (2015) tentang pengaruh pemilu presiden tahun 2014 terhadap abnormal return dan trading volume activity pada perusahaan yang tergabung dalamindeks Kompas100. Penelitian ini menemukan bahwa terdapat abnormal return yang signifikan selama periode peristiwa politik. Kondisi ini mengindikasikan adanya optimisme investor bahwa pemilu akan diselenggarakan pada tanggal 9 Juli 2014 dan terjadi peningkatan volume perdagangan saham pada sebelum dan setelah pemilihan Presiden 9 Juli 2014. Hasil penelitian ini juga sejalan dengan penelitian yang dilakukan oleh Diniar \& Kiryanto (2015), Kusumayanti \& Suarjaya (2018), Mahmood et al. (2014), Kabiru et al. (2015) dan Katti (2018) yang mendapatkan hasil bahwa terdapat abnormal return yangsignifikan pada periode sesudah peristiwa politik yang diteliti. Bertolak belakang dengan hasil penelitian sebelumnya, reaksi pasar modal terhadap peristiwa politik diteliti oleh Sudewa \& Sari (2015), Caroline (2016), dan Annisa (2017) yang menunjukkan tidak adanya reaksi pasar pada saat pelaksanaan pilpres 2014 serta tidak terdapat perbedaan rata - rata abnormal return antara sebelum serta sesudah peristiwa politik yang diteliti.

Perbedaan penelitian ini dengan penelitian terdahulu adalah: peneliti menggunakan event study peristiwa pemilihan umum serentak tahun 2019 dengan melakukan pengujian terhadap Abnormal Return saham dan Trading Volume Activity 10 hari kerja sebelum dan 10 hari kerja setelah peristiwa Pemilihan Umum Serentak tanggal 17 April 2019. Pemilihan Jakarta Islamic Index (JII) sebagai objek penelitian karena JII merupakan salah satu indeks saham syariah unggulan di Bursa Efek Indonesia. Proses pemilihan 30 saham yang masuk dalam indeks ini mempertimbangkan faktor likuiditas, kapitalisasi pasar, dan nilai transaksi, sehingga dengan jumlah sampel tersebut diharapkan dapat mengintepretasikan reaksi pasar modal di Indonesia terhadap peristiwa pemilu serentak tahun 2019. Berdasarkan uraian latar belakang di atas, maka penulis termotivasi untuk melakukan penelitian dengan judul "Analisis Abnormal Return dan Trading Volume Activity Sebelum dan Sesudah Pemilihan Umum Serentak Tahun 2019 (Studi Pada Saham Yang Tergabung Dalam Jakarta Islamic Index)”.

\section{TELAAH LITERATUR}

\section{Teori Persinyalan (Signaling Theory)}

Menurut signaling theory, informasi yang dipublikasikan sebagai suatu pengumuman akan memberikan sinyal bagi investor dalam pengambilan keputusan investasi. Jika pengumuman tersebut mengandung nilai positif, maka diharapkan pasar akan bereaksi pada waktu pengumuman tersebut diterima oleh pasar. Pada waktu informasi diumumkan dan semua pelaku pasar sudah menerima informasi tersebut, pelaku pasar terlebih dahulu menginterpretasikan dan menganalisis informasi tersebut sebagai sinyal baik (good news) atau sinyal buruk (bad news) (Hartono, 2017). 


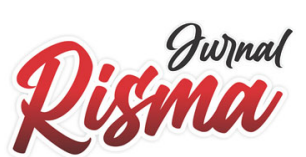

Vol. 1 No. 3 September 2021

\section{Teori Pasar Efisien (Market Efficient Theory)}

Konsep pasar efisien pertama kali dikembangkan oleh Fama (1970). Pasar efisien (market efficient) adalah suatu kondisi dimana informasi tentang semua harga dapat diperolehsecara terbuka dan cepat tanpa ada hambatan yang khusus (Fahmi, 2013: 260). Menurut Tandelilin (2017: 224) pasar yang efisien adalah pasar dimana harga semua sekuritas yang diperdagangkan telah mencerminkan semua informasi yang tersedia. Efisiensi pasarmengandung makna bahwa pelaku pasar akan bergerak secara bersama mengikuti perubahan yang terjadi. Perubahan yang terjadi tersebut berupa informasi yang diserap atau direspons oleh pasar secara efisien.

\section{Pasar Modal}

Pasar modal (capital market) merupakan pasar yang memperjual belikan berbagai instrumen keuangan jangka panjang atau efek. Instrumen keuangan jangka panjang tersebut dapat berbentuk utang atau modal sendiri (Zulfikar, 2016). Menurut Sunariyah (2006: 4) pengertian pasar modal secara umum adalah suatu sistem keuangan yang terorganisir, termasuk didalamnya adalah bank-bank komersial dan semua lembaga perantara dibidang keuangan, serta keseluruhan surat-surat berharga yang beredar.

\section{Studi Peristiwa (Event Study)}

Studi peristiwa (event study) merupakan studi yang mempelajari reaksi pasar terhadap suatu peristiwa (event) yang informasinya dipublikasikan sebagai suatu pengumuman. Event study dapat digunakan untuk menguji kandungan informasi dari suatu pengumuman dan dapat juga digunakan untuk menguji efisiensi pasar bentuk setengah kuat (Hartono, 2017: 643). Menurut MacKinley (1997: 13), event study sebagai salah satu metodologi penelitian yang menggunakan data•data pasar keuangan untuk mengukur dampak dari suatu kejadian yang spesifik terhadap nilai perusahaan, biasanya tercermin dari harga saham dan volume transaksinya.

\section{Jakarta Islamic Index}

Jakarta Islamic Index atau biasa disebut JII adalah salah satu indeks saham yang ada di Indonesia yang menghitung indeks harga rata-rata saham untuk jenis saham-saham yang memenuhi kriteria syariah. JII telah dikembangkan sejak tanggal 3 Juli 2000. Setiap periodenya, saham yang masuk JII berjumlah 30 (tiga puluh) saham yang memenuhi kriteria syariah (www.wikipedia.org).

\section{Abnormal Return}

Reaksi pasar akibat terjadinya suatu peristiwa dapat diamati melalui perubahan harga saham yang diukur dengan adanya abnormal return. Sebagaimana disebutkan dalam Hartono (2017: 609) bahwa suatu pengumuman yang memiliki kandungan informasi akan memberikan abnormal return kepada pasar. Return tak normal atau abnormal return (AR it) adalah selisih (positif atau negatif) dari return realisasi diseputar peristiwa $\left(\mathrm{R}_{\mathrm{it}}\right)$ dengan returnekspektasi $\mathrm{E}\left(\mathrm{R}_{\mathrm{it}}\right)$. Apabila tidak terdapat peristiwa, return realisasi $\left(\mathrm{R}_{\mathrm{it}}\right)$ cenderung tidak berbeda dengan return ekspektasi $\mathrm{E}\left(\mathrm{R}_{\mathrm{it}}\right)$.

\section{Trading Volume Activity}

Menurut Wirajaya (2009: 7), Trading Volume Activity (TVA) adalah jumlah saham yang diperdagangkan selama satu hari perdagangan. Semakin besar volume perdagangan suatu saham, menunjukkan bahwa saham tersebut aktif dan sering ditransaksikan di pasar modal. Suatu pengumuman yang tidak membawa informasi baru tidak akan mengubah kepercayaan investor sehingga mereka tidak akan melakukan perdagangan. 


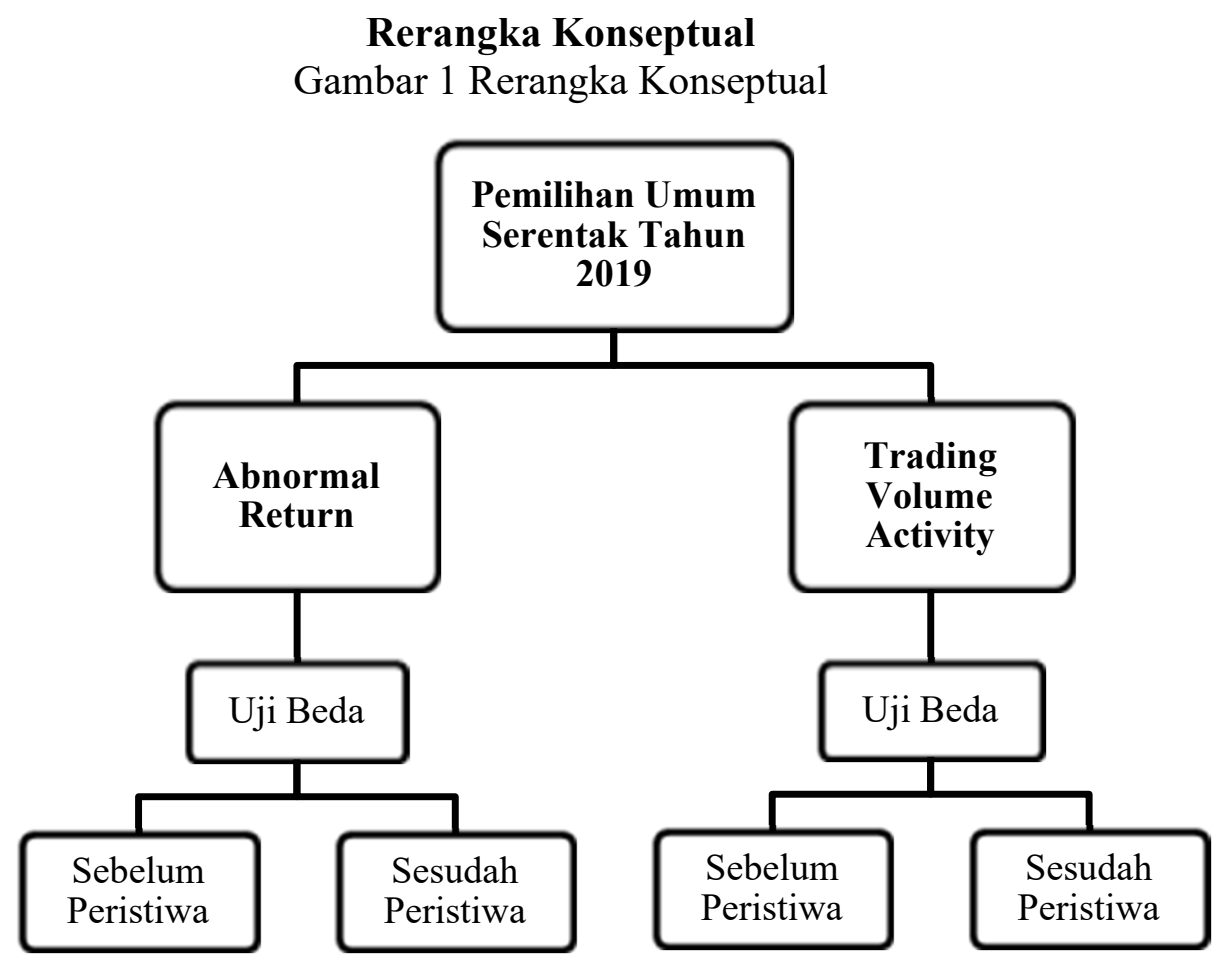

\section{Hipotesis Penelitian}

Pasar bereaksi terhadap informasi merupakan hal yang sangat penting karena dapat mengakibatkan perubahan harga yang menimbulkan abnormal return di sekitar peristiwa serta perubahan persepsi investor untuk mengambil keputusan investasi.

$\mathrm{H}_{1}$ : Terdapat perbedaan Abnormal Return sebelum dan sesudah peristiwa Pemilihan Umum Serentak tahun 2019 pada saham yang tergabung dalam Jakarta Islamic Index. Tingkat permintaan saham yang berbeda dengan penawaran saham dipengaruhi oleh pengharapan investor terhadap suatu saham apakah optimis atau pesimis. Apabila investor mengartikan sebagai isyarat positif atas suatu informasi maka tingkat permintaan saham akan lebih tinggi dari pada penawaran saham yang ada, sehingga volume perdagangan saham diperkirakan meningkat.

$\mathrm{H}_{2}$ : Terdapat perbedaan Trading Volume Activity sebelum dan sesudah peristiwa Pemilihan Umum Serentak tahun 2019 pada saham yang tergabung dalam Jakarta Islamic Index.

\section{METODE PENELITIAN}

\section{Jenis Penelitian}

Jenis penelitian yang digunakan dalam penelitian ini adalah penelitian komparatif dengan pendekatan studi peristiwa (event study).

\section{Populasi dan Sampel}

Populasi dalam penelitian ini adalah seluruh perusahaan yang tergabung sebagai anggota Jakarta Islamic Index yaitu berjumlah 30 perusahaan. Pengambilan sampel dalam penelitian ini dilakukan dengan metode sampel jenuh sehingga sampel yang digunakan adalah seluruh saham perusahaan yang tergabung dalam indeks saham JII periode Desember 2018 sampai dengan Mei 2019 yang berjumlah 30 perusahaan. 


\section{Variabel Penelitian}

\section{Abnormal Return}

Abnormal return merupakan kelebihan dari return realisasi terhadap return normal. Return normal merupakan return ekspektasi (return yang diharapkan investor). Dengan demikian, return tak normal adalah selisih antara return realisasi dengan return ekspektasi (Hartono, 2017: 667). Pada penelitian ini, metode yang digunakan untuk menghitung return ekspektasi adalah market adjusted model, model ini menganggap bahwa penduga terbaik untuk mengestimasi return suatu sekuritas yaitu return indeks pasar pada saat tersebut.

\section{Average Abnormal Return}

Pengujian adanya abnormal return tidak dilakukan untuk tiap-tiap sekuritas, tetapi dilakukan secara agregat dengan menguji rata-rata return tak normal seluruh sekuritas secara cross-section untuk tiap-tiap hari pada periode peristiwa.

\section{Trading Volume Activity}

Volume perdagangan saham merupakan besarnya jumlah lembar saham yang diperdagangkan pada waktu tertentu. Trading volume activity adalah salah satu pendekatan yang digunakan untuk melihat reaksi pasar modal terhadap informasi melalui parameter pergerakan aktivitas volume perdagangan saham di pasar. Rumus untuk menghitung TVA adalah sebagai berikut (Hartono, 2017: 447):

\section{Average Trading Volume Activity}

Average trading volume activity adalah rata-rata jumlah seluruh saham yang diperdagangkan per hari selama periode peristiwa

\section{Prosedur Analisis DataUji Normalitas}

Analisis data dalam penelitian kuantitatif membutuhkan persyaratan bahwa data berdistribusi normal, sehingga dibutuhkan melakukan uji normalitas. Pengujian normalitas data dimaksudkan untuk melihat normal tidaknya sebaran data yang akan dianalisis (Sinambela, 2014: 223). Uji normalitas yang digunakan dalam penelitian ini adalah uji statistik dengan metode Kolmogorov-Smirnov (K-S).

\section{Uji Hipotesis}

Uji hipotesis yang digunakan dalam penelitian ini adalah menggunakan uji beda rata-rata dua sampel. Uji beda dua sampel ini dibedakan menjadi dua jenis yaitu uji beda dua sampel berhubungan (related) dan uji beda dua sampel independen. Dalam penelitian ini yang digunakan adalah pengujian sampel berpasangan. Metode pengujian yang digunakan adalah Paired Sample T-Test dan Wilcoxon Signed Ranks Test. 


\section{HASIL DAN PEMBAHASAN \\ Hasil Uji Normalitas}

Tabel 1

Hasil Uji Normalitas AAR One-Sample Kolmogorov-Smirnov Test

\begin{tabular}{llrr}
\hline $\mathrm{N}$ & & AAR_SebelumAAR_Sesudah \\
\hline Normal Parameters $\mathrm{a}, \mathrm{b}$ & Mean & 10 & 10 \\
\cline { 2 - 4 } & Std. Deviation & -.00047050 & -.00125300 \\
\hline Most Extreme Differences & Absolute & .004727303 & .006034471 \\
\cline { 2 - 4 } & Positive & .214 & .114 \\
\cline { 2 - 4 } & Negative & .214 & .114 \\
\hline Test Statistic & & .188 & -.094 \\
\hline Asymp. Sig. (2-tailed) & & .214 & .114 \\
\hline
\end{tabular}

Sumber : data diolah, 2020

Berdasarkan hasil uji normalitas pada tabel 1 dapat diketahui bahwa nilai Asymp. Sig. (2tailed) dari abnormal return 10 hari sebelum dan 10 hari setelah peristiwa pemilihan umum serentak tahun 2019 pada emiten yang terdaftar di Jakarta Islamic Index diperoleh nilai sebesar 0,200 dan 0,200. Berdasarkan kriteria pengambilan keputusan pada uji normalitas, jika nilai Asymp. Sig (2-tailed) $>$ tingkat signifikansi $(0,05$ atau $\alpha=5 \%)$, maka data berdistribusi normal.

Tabel 2

Hasil Uji Normalitas ATVA

\section{One-Sample Kolmogorov-Smirnov Test}

ATVA_SebelumATVA_Sesudah

\begin{tabular}{llrr}
\hline $\mathrm{N}$ & & 10 & 10 \\
\hline Normal Parameters ${ }^{\mathrm{a}, \mathrm{b}}$ & Mean & .00161630 & .00173430 \\
\cline { 2 - 4 } & Std. Deviation & .000313313 & .000563418 \\
\hline Most Extreme Differences & Absolute & .227 & .272 \\
\cline { 2 - 4 } & Positive & .227 & .272 \\
\cline { 2 - 4 } & Negative & -.141 & -.238 \\
\hline Test Statistic & & .227 & .272 \\
\hline Asymp. Sig. (2-tailed) & & $.155^{\mathrm{c}}$ & $.035^{\mathrm{c}}$ \\
\hline
\end{tabular}

Sumber : data diolah, 2020

Berdasarkan hasil uji normalitas pada tabel 2 dapat diketahui bahwa nilai Asymp. Sig. (2tailed) dari trading volume activity 10 hari sebelum dan 10 hari setelah peristiwa pemilihan umum serentak tahun 2019 diperoleh nilai sebesar 0,155 dan 0,035. Berdasarkan kriteria pengambilan keputusan pada uji normalitas, jika nilai Asymp. Sig (2tailed $)>$ tingkat signifikansi $(0,05$ atau $\alpha=5 \%)$, maka data ATVA sebelum peristiwa berdistribusi normal.sedangkan ATVA sesudah peristiwa tidak berdistribusi normal 


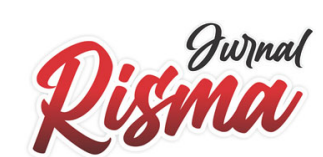

Vol. 1 No. 3 September 2021

karena nilai Asymp. Sig. (2-tailed) sebesar 0,035 lebih kecil dari tingkat signifikansi 0,05.

\section{Hasil Uji Hipotesis}

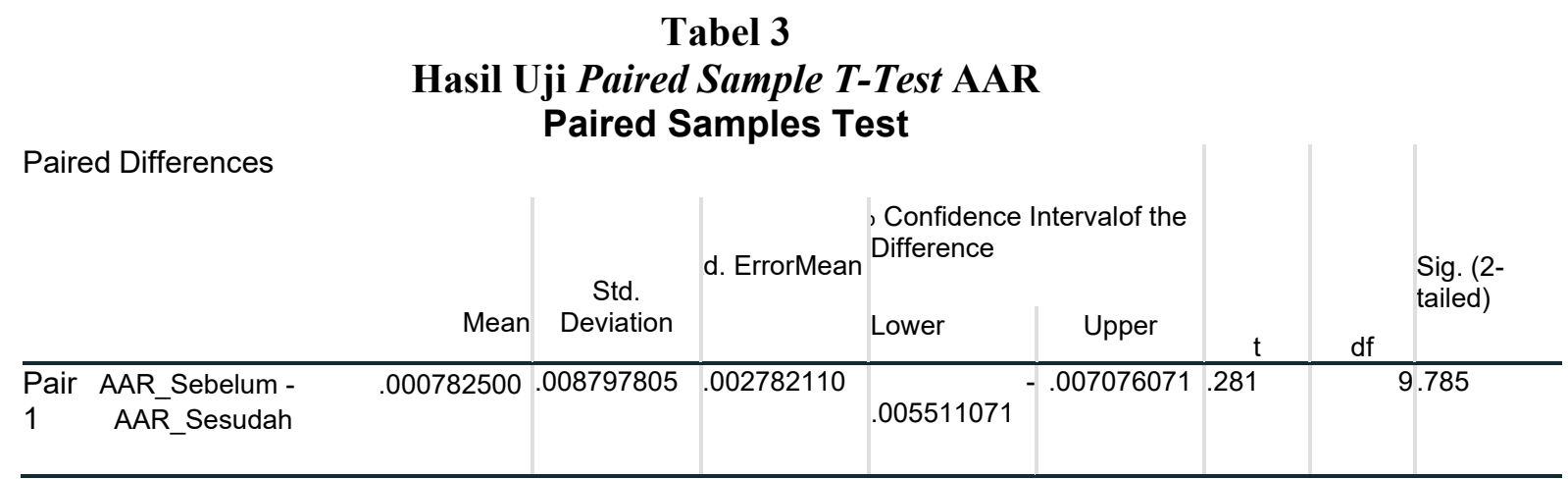

Sumber : data diolah, 2020.

Tabel 3 di atas memperlihatkan bahwa nilai Sig. (2-tailed) sebesar 0,785. Sesuai dengan kriteria pengambilan keputusan pada uji Paired Sample T-Test apabila nilai Sig. (2-tailed) $>$ tingkat signifikansi $(0,05)$, maka dapat dikatakan $\mathrm{H}_{01}$ diterima dan $\mathrm{H}_{\mathrm{a} 1}$ ditolak sehingga dapat disimpulkan bahwa Abnormal Return sesudah peristiwa pemilihan umum serentak tahun 2019 tidak memiliki perbedaan yang signifikan dengan Abnormal Return sebelum pemilihan umum serentak tahun 2019.

\footnotetext{
Tabel 4

Hasil Uji Wilcoxon Signed Ranks Test ATVA

Test Statistics ${ }^{a}$

ATVA_Sebelum -

\begin{tabular}{lr} 
& ATVA Sesuda \\
Asymp. Sig. (2-tailed) & .878 \\
\hline
\end{tabular}

a. Wilcoxon Signed Ranks Test

b. Based on positive ranks.

Sumber : data diolah, 2020.

Berdasarkan uji normalitas pada variabel ATVA tidak berdistribusi normal maka pengujian hipotesis menggunakan Wilcoxon Signed Ranks Test. Berdasarkan tabel 4 tersebut menunjukkan bahwa Wilcoxon Signed Ranks Test menghasilkan nilai Asymp. Sig. (2-tailed) sebesar 0,878. Dengan demikian karena nilai Sig. (2-tailed) $>$ tingkat signifikansi $(0,05)$, maka dapat dikatakan $\mathrm{H}_{02}$ diterima dan $\mathrm{H}_{\mathrm{a} 2}$ ditolak. Oleh karena itu, dapat disimpulkan bahwa Trading Volume Activity sesudah peristiwa pemilihan umum serentak tahun 2019 tidak memiliki perbedaan yang signifikan dengan Trading Volume Activity sebelum peristiwa pemilihan umum serentak tahun 2019.
} 


\section{Kesimpulan}

\section{KESIMPULAN DAN SARAN}

Berdasarkan hasil penelitian mengenai analisis Abnormal Return dan Trading Volume Activity sebelum dan sesudah peristiwa Pemilihan Umum Serentak Tahun 2019 pada Jakarta Islamic Index maka dapat ditarik kesimpulan sebagai berikut :

1. Tidak terdapat perbedaan rata-rata abnormal return saham 10 hari sebelum dan 10 hari setelah peristiwa Pemilihan Umum Serentak Tahun 2019 pada Jakarta Islamic Index. Hal ini ditunjukkan dengan nilai Sig. (2-tailed) sebesar 0,785 > tingkat signifikansi $(0,05)$, maka dapat dikatakan $\mathrm{H}_{01}$ diterima dan $\mathrm{H}_{\mathrm{a} 1}$ ditolak.

2. Tidak terdapat perbedaan rata-rata trading volume activity saham 10 hari sebelum dan 10 hari setelah peristiwa Pemilihan Umum Serentak Tahun 2019 pada Jakarta Islamic Index. Hal ini ditunjukkan dengan nilai Asymp. Sig. (2-tailed) sebesar 0,878 $>$ tingkat signifikansi $(0,05)$, maka dapat dikatakan $\mathrm{H}_{02}$ diterima dan $\mathrm{H}_{\mathrm{a} 2}$ ditolak.

\section{Keterbatasan dan Saran}

Berdasarkan kesimpulan di atas maka saran yang penulis ajukan kepada pihak•pihak yang terkait dalam penelitian ini adalah sebagai berikut :

1. Penelitian ini hanya menggunakan satu indeks saham, untuk penelitian selanjutnya yang memiliki fokus yang sama mungkin dapat menambahkan sampel penelitian dengan menggunakan seluruh perusahaan yang tercatat di Bursa Efek Indonesia sebagai sampel penelitian. Penambahan sampel penelitian yang lebih besar ini diharapkan agar dapat menghasilkan hasil pengujian yang lebih akurat mengenai pengaruh peristiwa politik terhadap pasar modal Indonesia.

2. Bagi para investor tidak perlu khawatir terhadap informasi peristiwa Pemilihan Umum Serentak Tahun 2019 karena peristiwa tersebut tidak berpengaruh signifikan pada abnormal return dan trading volume activity saham pada emiten yang tergabung dalam Jakarta Islamic Index.

3. Pada penelitian ini perhitungan abnormal return menggunakan Market Adjusted Model sehingga disarankan bagi peneliti selanjutnya untuk menghitung expected return dengan model yang lain atau ketiga model perhitungan yang ada sehingga perbedaan hasil dari ketiga model tersebut bisa terlihat.

\section{DAFTAR PUSTAKA}

Alkaff, Maria Qifthiyah. 2010. Pengaruh Pemilihan Presiden RI Tahun 2009 terhadap Harga Saham dan Volume Perdagangan Saham Perusahaan Di Bursa Efek Indonesia. Skripsi. Universitas Pembangunan Nasional "Veteran", Jawa Timur.

Annisa, Sarin Alvi. 2017. Reaksi Pasar Modal Indonesia Terhadap Peristiwa Pemilihan Umum Presiden RI Tahun 2014 Pada Jakarta Islamic Index. Skripsi. Institut Agama Islam Negeri Surakarta.

Caroline, Olivia. 2016. Analisis Reaksi Pasar Modal Indonesia terhadap PeristiwaPeristiwa Ekonomi dan Sosial-Politik Dalam Negeri. Skripsi. Universitas Bunda Mulia, Jakarta.

Diniar, Ayudia Hanung, \& Kiryanto. 2015. Analisis Dampak Pemilu Presiden Jokowi terhadap Return Saham (Studi Kasus Saham LQ-45 di Bursa Efek Indonesia). Jurnal Akuntansi Indonesia, Vol. 4 No. 2 Juli 2015: 97-108.

Fahmi, Irham. 2013. Pengantar Pasar Modal. Bandung: Alfabeta.

Fama, E. F. 1970. Efficient Capital Markets: A Review of Theory and Empirical Work.Journal of Finance 25, hlm. 383-417.

Ghozali, Imam. 2005. Aplikasi Analisis Multivariate dengan Program SPSS. Semarang: 


\section{Badan Penerbit-UNDIP.}

Goodell J.W \& S. Vähämaa. 2013. US Presidential Elections End Implied Volatility: TheRole of Political Uncertainty. Journal of Banking and Finance 27:1108-1117. Hartono, Jogiyanto. 2017. Teori Portofolio dan Analisis Investasi. Yogyakarta: BPFE Yogyakarta.

Hartono, Jogiyanto. 2018. Metode Penelitian Bisnis. Yogyakarta: BPFE Yogyakarta.

Husnan, Suad. 2004. Dasar-Dasar Teori Portofolio dan Analisis Sekuritas. Yogyakarta: UPPAMP YKPN.

Kabiru, James Ndungu et al. 2015. The Effect of General Elections on Stock Returns at the Nairobi Securities Exchange. European Scientific Journal October 2015 edition vol.11, No.28.

Karmila. 2010. Seluk Beluk Pasar Modal. Yogyakarta: Kompetensi Terapan Sinergi Pustaka. Katti, Siti Wardani Bakri. 2018. Pengaruh Peristiwa Politik (Pemilu Presiden dan

Pengumuman Susunan Kabinet) Terhadap Saham Sektor Industri Di Bursa Efek Indonesia. Jurnal Capital Universitas Merdeka Madiun, Vol. 1 No. 2 Maret 2018.

Kusumayanti, Kadek Ria \& Anak Agung Gede Suarjaya. 2018. Reaksi Pasar Modal Indonesia terhadap Pengumuman Kemenangan Donald Trump dalam Pilpres Amerika Serikat 2016. E-Jurnal Manajemen Unud, Vol. 7, No. 4, 2018: 1713-1741.

Lehkonen, H. \& Heimonen, K. 2015. Democracy, Political Risks and Stock Market Performance. Journal of International Money and Finance, 59, 77-99.

MacKinlay, A. Craig. 1997. Event Studies in Economic and Finance. Journal of Economics Literature, Vol. XXXV (March 1997), pp. 13-39.

Mahmood, Shahid et al. 2014. Impact of Political Events on Stock Market: Evidence from Pakistan. Journal of Asian Business Strategy 2014:163-174.

Murdifi et al. 2018. Efek Peristiwa Politik terhadap Kinerja Pasar Modal Indonesia (Even Study Pada Vonis Yang Diberikan Kepada Basuki Tjahaja Purnama). E-JRA Vol. 07No. 06 Agustus 2018.

Pamungkas, Aryo et al. 2015. Pengaruh Pemilu Presiden Indonesia Tahun 2014 Terhadap Abnormal Return dan Trading Volume Activity (Studi Pada Perusahaan Pada Perusahaan yang Tercatat Sebagai Anggota Indeks Kompas 100). Jurnal Administrasi Bisnis (JAB), Vol. 20 No. 1 Maret 2015.

Purbolaksono, Arfianto. 2019. "Evaluasi Pemilu Serentak 2019". www.theindonesianinstitute.com/evaluasi-pemilu-serentak-2019/ (diakses tanggal 23 Oktober 2019).

Sihotang, Eva Maria \& Peggy Adeline Mekel. 2015. Reaksi Pasar Modal terhadap Pemilihan Umum Presiden Tanggal 9 Juli 2015 di Indonesia (Studi di Perusahaan Konstruksi, Infrastruktur dan Utilitas pada BEI, Jakarta). Jurnal EMBA Vol.3 No. 1 Maret 2015. Hal. 951-960.

Silaen, Sofar \& Widiyono. 2013. Metodologi Penelitian Sosial untuk Penulisan Skripsi dan Tesis. Jakarta: IN MEDIA.

Sinambela, Lijan Poltak. 2014. Metodologi Penelitian Kuantitatif. Yogyakarta: GRAHA ILMU.

Sudewa. Dewa Gede Oka \& Maria M. Ratna Sari. 2015. Reaksi Pasar Atas Peristiwa Pilpres2014. E-Jurnal Akuntansi Universitas Udayana 12.3 (2015): 465-480.

Sudirman. 2015. Pasar Modal dan Manajemen Portofolio. Makasar: Sultan Amai Press. Sunariyah. 2006. Pengantar Pengetahuan Pasar Modal. Yogyakarta: UPP STIM YKPN. Suryani \& Hendryadi. 2016. Metode Riset Kuantitatif. Jakarta: 
PRENADAMEDIA GROUP. Suwardjono. 2005. Teori Akuntansi Perekayasaan Pelaporan Keuangan. Yogyakarta: BPFE Yogyakarta.

Tandelilin, Eduardus. 2017. Manajemen Portofolio dan Investasi. Yogyakarta: BPFEYogyakarta.

Zulfikar. 2016. Pengantar Pasar Modal dengan Pendekatan Statistika. Yogyakarta: Deepublish.

www.idx.co.id (diakses tanggal 30 September 2019).

www.cnnindonesia.com/ekonomi/20190520123710-92-396439/bei-akui-kondisi politiktimbulkan-kekhawatiran-pasar-saham (diakses tanggal 30 September 2019).

www.cnnindonesia.com/nasional/20190507084423-32-392531/total-554-orang-kppspanwas-dan-polisi-tewas-di-pemilu-2019 (diakses tanggal 6 November 2019).

www.wikipedia.org/wiki/Jakarta_Islamic_Index (diakses tanggal 26 Februari 2020). 